what counts as wise? Second, does the public, after considerable thought, think that our society has a moral obligation to pursue lines of research which may benefit present and future generations? I say "moral obligation" because it is sometimes implied by advocates of recombinant DNA research that science would be guilty of a sin of omission if it did not continue and promote research so promising in theoretical and practical benefits. I would prefer to say that the research is desirable and valuable, but by no means is it, morally obligatory. It is just one choice among many we can make in allocating our scientific resources. But I would like to know what the public - after due consideration-thinks about all that. Third, what does the public think about risks and benefits? How, in some rational way, ought the public to think about that problem?

One obvious implication of this line of thinking is that the public has as much obligation to act responsibly as does the scientific community. The calls for socially responsible scientists could well be matched with some concern about a socially responsible public. The future of the recombinant DNA debate will depend on the quality of the dialogue between the scientific community and the public. Neither side can conduct the debate on its own. The public must be kept informed in the future, must have a central role in present policy formation, and must develop standards by which to judge the issues. Scientists must bring their knowledge, and just as important, their lack of knowledge out into the open, not just once but again and again.

The public and the scientific community have now begun to talk. This marriage can be saved.

Daniel Callahan is director of the Hastings Center. This article is adapted from a presentation to the Academy Forum, National Academy of Sciences, in Washington, D.C. on March 7, 1977.

\title{
Who Decides Who Decides?
}

\section{I}

$t$ is a basic belief of most university faculty members and, indeed, of educated people everywhere in the West that freedom of inquiry must not be constrained in any arbitrary manner, especially not by persons outside the community of peers associated with the inquiry. It is, however, an increasingly challenged belief.

If the university were to forfeit, through citizen involvement, its exclusive right (within NIH regulations) to determine whether recombinant DNA research should be undertaken, it would very likely be establishing a precedent not only with regard to freedom of inquiry in this area but in any other area of the natural or social sciences where members of the community could argue that they were being put at physical or emotional risk by the research process itself or its possible products. Given changes in attitudes toward science, participation, and decision making, such a precedent would profoundly disrupt the elaborate and subtle mechanisms that motivate and guide science and sys-

This excerpt is reprinted with permission from Stephen Stich and David Jackson, editors, The Recombinant DNA Debate, to be published in 1977 by the University of Michigan Press. tematic inquiry in general. Consequences would be as unpredictable and possibly as societally catastrophic as those feared from the DNA research itself. However, some would argue (myself included) that the very fact of growing challenges to the ethic of freedom of inquiry and to its maintenance through "duly constituted authority," make it all the more necessary to discover new ways of reconciling the demands for participation by those putatively at risk with demands for protection of inquiry. It is going to take time and much experience to learn what values and techniques work and the hour is already late.

The first question we could ask is: "What is the appropriate geographic and temporal scale from which to draw the decision makers?" With chimeric biological materials it is impossible to anticipate how widespread will be the consequences for natural life forms. Therefore the appropriate decision-maker pool would seem to include the whole world as well as future generations since everyone, especially future generations, may be the deliberate or inadvertent beneficiaries or casualties of this research. But there is no such decision-making capability on the world level; the initial examination of the risks in recombinant DNA research, undertaken by involved scientists during a self-imposed moratorium, is as close to world-scale participation as we've come.

We are thus thrown back on the nation as more appropriate than the immediate environs around the research laboratory for making decisions that have such profound consequences over space and time. The NIH guideline deliberations were an exceptional and on the whole admirable experiment in this direction though these lacked sophisticated studies delineating the long-term social costs and benefits of the research, in part because we know too little. Moreover, the question of who would be entitled to participate in decisions about risks in the proximate area of the research was left unexamined. But the fundamental flaw in the NIH approach was that it reinforced the usual mode of operation-geographically separate institutions compete for funds and for the prestige won through successful research. This mode inevitably puts a premium on getting there "first with the most," and it focuses concern at the local level over whether to incur the associated risks.

Making decisions in areas of changing values, risks, and ambiguities require profound, perhaps radical, changes in the norms by which decision-making entities in research-oriented organizations operate.

-Donald N. Michael University of Michigan 